\title{
An anti-CAPN5 intracellular antibody acts as an inhibitor of CAPN5-mediated neuronal degeneration
}

\author{
Yan Wang ${ }^{1}$, Xiao Zhang ${ }^{1}$, Zongming Song ${ }^{1,2}$ and Feng Gu ${ }^{1}$ \\ ${ }^{1}$ State Key Laboratory, Key Laboratory of Vision Science, Ministry of Health, Zhejiang Provincial Key Laboratory of Ophthalmology \\ and Optometry, School of Ophthalmology and Optometry, Eye Hospital, Wenzhou Medical University, Wenzhou, Zhejiang \\ 325027, China \\ ${ }^{2}$ Henan Eye Institute, Henan Eye Hospital, Henan Provincial People's Hospital, People's Hospital of Zhengzhou University, \\ Zhengzhou, Henan 450003, China \\ Correspondence to: Feng Gu, email: gufenguw@gmail.com \\ Keywords: CAPN5; retinal degeneration; photoreceptor; sCFv; inhibitor \\ Received: May 26, $2017 \quad$ Accepted: October 03, $2017 \quad$ Published: November 01, 2017 \\ Copyright: Wang et al. This is an open-access article distributed under the terms of the Creative Commons Attribution License 3.0 \\ (CC BY 3.0), which permits unrestricted use, distribution, and reproduction in any medium, provided the original author and source \\ are credited.
}

\section{ABSTRACT}

CAPN5 has been linked to autosomal dominant neovascular inflammatory vitreoretinopathy (ADNIV). Activation of CAPN5 may increase proteolysis and degradation of a wide range of substrates to induce degeneration in the retina and the nerve system. Thus, we developed an inhibitory intracellular single chain variable fragment (scFv) against CAPN5 as a potential way to rescue degeneration in ADNIV disease or in neuronal degeneration. We report that overexpression CAPN5 increases the levels of the auto-inflammatory factors toll like receptor 4 (TLR4), interleukin 1 alpha (IL1alpha), tumor necrosis factor alpha (TNFalpha) and activated caspase 3 in $661 \mathrm{~W}$ photoreceptor-like cells and SHSY5Y neuronal-like cells. Both C4 and C8 scFvs specifically recognize human/mouse CAPN5 in $661 \mathrm{~W}$ cells and SHSY5Y cells, moreover, both the C4 and C8 scFvs protected cells from CAPN5-induced apoptosis by reducing the levels of activated caspase 3 and caspase 9. The cellular expression C4 ScFv reduced levels of the pro-inflammatory factor IL1-alpha activated caspase 3 in cells after CAPN5 overexpression. We suggest that CAPN5 expression has important functional consequences in auto-inflammatory processes, and apoptosis in photoreceptor like cells and neural-like cells. Importantly, the specific intracellular targeting of antibody fragments blocking activation of CAPN5 act as inhibitors of CAPN5 functions in neural like cells, thus, our data provides a novel potential tool for therapy in CAPN5-mediated ADNIV or neurodegenerative diseases.

\section{INTRODUCTION}

CAPN5 encodes calpain-5, a member of the calcium-activated cysteine protease family [1,2]. CAPN5 has been associated with autosomal dominant neovascular inflammatory vitreoretinopathy (ADNIV) [3-6], obesity [7], Huntington's disease [8, 9], and polycystic ovary syndrome [10]. CAPN5 has been found to be localized in the cytoplasm and nucleus of photoreceptor cells, neuronal cells in the retina, and also in the central nervous system $[11,12]$. The members of the calpain family usually show elevated proteolytic functions in nervous system diseases. Calpain is a ubiquitous calcium-sensitive protease that is essential for normal physiologic neuronal function [13]. However, alterations in calcium homeostasis lead to persistent, pathologic activation of calpain in a number of neurodegenerative diseases [14]. Pathologic activation of calpain induces the cleavage of substrates that negatively affect neuronal structure and function, leading to inhibition of essential neuronal survival mechanisms [15]. Thus, Inhibition of activated calpain represents an ideal therapeutic strategy in brain injury [16-18], Alzheimer's disease [19], Parkinson's disease [20], Huntington's disease [8], multiple sclerosis [21], optic injury [22], as well as retinal degenerative diseases [23]. The C. elegans ortholog of CAPN5, TRA-3, has 
essential regulated functions for necrotic neuronal death $[24,25]$. Autosomal dominant neovascular inflammatory vitreoretinopathy (ADNIV) is an inherited autoimmune uveitis and vitreoretinal degeneration [26]. ADNIV is caused by mutations of the CAPN5 gene which leads to photoreceptor degeneration, autoimmune uveitis, and retinal neovascularization. It has been found that mutations of CAPN5 activated CAPN5 protein that generates the various pathological features involved in blindness and could be therapeutically relevant $[27,28]$.

Because activating mutations of CAPN5 play pivotal roles and have a significant effect on degeneration of photoreceptor cells at an early stage in human ADNIV patients [3-6], we generated intracellularly expressed single chain antibody fragments against CAPN5 to block possible active-CAPN5 substrate-mediated cell damage including apoptosis, autoimmune-activation, and retinal photoreceptor cell degeneration. This may be a possible way to treat of activated-CAPN5 induced photoreceptor cell and neuronal cell degeneration in ADNIV and neurodegenerative diseases.

\section{RESULTS}

\section{Overexpression of CAPN5 induces apoptosis and expression of pro-inflammatory factors in neuronal cells}

It has been shown that CAPN5 activation may induce degeneration of photoreceptor cells in the eye and neuronal cell death in the nerve system $[6,9]$. To characterize the roles of CAPN5 in photoreceptor cells and neuronal-like cells, we transfected plasmids (CAPN5 ${ }^{\mathrm{wt}}$ and CAPN5 $5^{\mathrm{R} 289 \mathrm{~W}}$ ) into $661 \mathrm{~W}$ cells, N2A cells and SHSY5Y cells, respectively. After 24, 48, 72 hours transfections in $661 \mathrm{~W}$ and N2A cells, the cell viability of $661 \mathrm{~W}$ and N2A were both strongly reduced by CAPN5 and CAPN5 R289W overexpression in a time-transfection dependent manner (Figure 1A, 1B). Moreover, The CAPN5 mutant R289W overexpression decreased the more viability of cells when compared to CAPN5 wt transfections in both $661 \mathrm{~W}$ and N2A cell lines. After 60 hours post-transfection, both the CAPN5 and CAPN5 mutant R289W vectors transfection increased the mRNA levels of TLR4/6, IL1alpha and TNFalpha when compared to empty vector transfection, and this was especially pronounced for the mutant CAPN5 R289W expression which increased both caspase 3 activation and IL1alpha levels when compared to CAPN5 wt transfection in both $661 \mathrm{~W}$ and SHSY5Y Cell lines (Figure 1C, 1D). After 60 hours transfections, we also detected the protein levels of TLR4 $(p<0.05$, 1.6 folds in CAPN5 wt; $p<0.01,-2.3$ folds in CAPN5 R289W in 661 W cells. $p<0.05,-1.7$ folds, in CAPN5wt; -2.2 folds in CAPN5 R289W in SHSY5Y cells), IL1 alpha $(p<0.05,-1.4$ folds in CAPN5 wt; $p<0.001,-2.0$ folds in CAPN5 R289W in $661 \mathrm{~W}$ cells. $p<0.05,-1.5$ folds in CAPN5wt; $p<0.01,-2.4$ folds in CAPN5 R289W in SHSY5Y cells), TNF alpha $(p<0.05,-1.5$ folds in CAPN5 wt; $p<0.01,-2.2$ folds in CAPN5 R289W in $661 \mathrm{~W}$ cells. $p<0.05,-1.8$ folds in CAPN5 wt, $p<0.01,-2.2$ folds in CAPN5 R289W in SHSY5Y cells) were increased by CAPN5 overexpressions $(p<0.001,-1.8$ folds in $661 \mathrm{~W}$ cells; $p<0.01,-1.6$ folds in SHSY5Y cells). Moreover, expression of CAPN5 R289W led to higher protein levels of TLR4, IL1 alpha and activated caspase 3 in both cell lines (Figure 1E, 1F, 1G, 1H). These data indicate that CAPN5 exerts its effects on TLR4/IL1/TNF alpha expression at the transcriptional level, and overexpression of CAPN5 increased caspase 3 activation and expression of pro-inflammatory proteins as TLR4, IL1alpha and TNF alpha. It is interesting that the mutant CAPN5 R289W shows the stronger effects on caspase 3 activation and protein levels of the TLR4 pathway when compared to wild-type CAPN5 overexpression in neuronal cells. We also have been found that overexpression of CAPN5 vectors shortened neurite lengths in mouse neuroblastoma N2A cells when compared to empty vector control transfection (data not shown). Together, these results suggest that overexpression CAPN5 induces activation of auto-inflammation and apoptosis in neural-like cells.

\section{Screening and selection of specific CAPN5 scFvs by phage display}

Activating CAPN5 mutations have been shown accelerate the degeneration of photoreceptor cells, autoimmunity inflammatory in retinal cells, and neuronal cell death in the nervous system [27, 28]. To design an inhibitor of CAPN5 to protect cells, we used phage display to screen scFvs against human CAPN5. We purified and selected three scFvs we called $\mathrm{C} 4$ and C8, C20 (Figure 2A) binds to the purified CAPN5 by direct ELISA. Both $\mathrm{C} 4$ and $\mathrm{C} 8 \mathrm{scF} v \mathrm{~s}$ did not bind to normal mouse IgG or BSA (Figure 2B, 2C). We detected C20 scFv non-specific binding characteristics by ELISA (Figure 2D). To confirm whether $\mathrm{C} 4$ and $\mathrm{C} 8 \mathrm{scF}$ vs antibodies reacted with wild type CAPN5 protein in cells, we incubated $\mathrm{C} 4 \mathrm{scFv}$ and $\mathrm{C} 8 \mathrm{scFv}$ with total proteins from $661 \mathrm{~W}$ cell lysates which separated and transferred onto PVDF membrane, then incubated membrane with anti-His tag and detected the signals by secondary antibody. In immunoblot assay, we found the specific $75 \mathrm{kDa}$ band was detected by both $\mathrm{C} 4$ and $\mathrm{C} 8 \mathrm{scFvs}$, the bands at $75 \mathrm{kDa}$ were seem as the band detected by a commercial anti-CAPN5 antibody (Figure $2 \mathrm{E}$ ). We also pre-incubated the living cells with $\mathrm{C} 4 / \mathrm{C} 8$ scFvs for 2 hours, then fixed cells, incubated cells with anti-His tag/ a commercial goat anti-CAPN5 antibody respectively, following with secondary antibodies. We found that scFvs bind to cytoplasmic CAPN5, the immunofluorescence signal co-localized with signals detected by the commercial antibody against CAPN5 in $661 \mathrm{~W}$ cells and human SHSY5Y cells (Figure 2F). These 
A

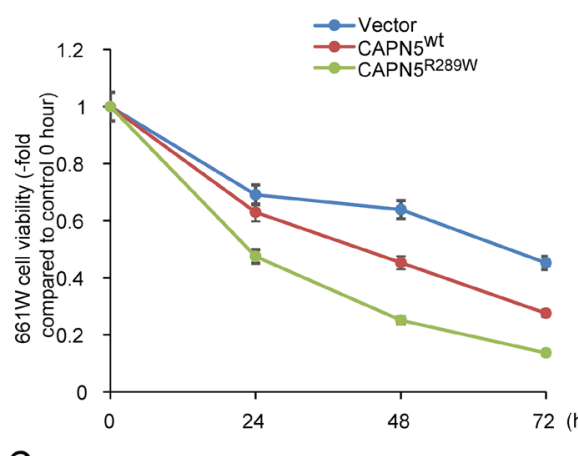

C

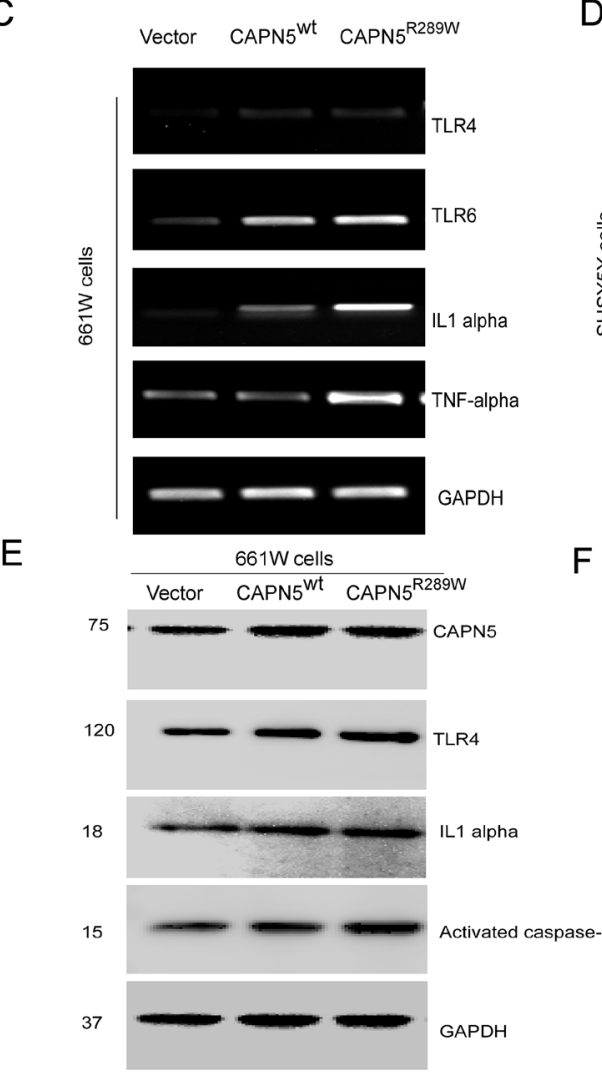

D

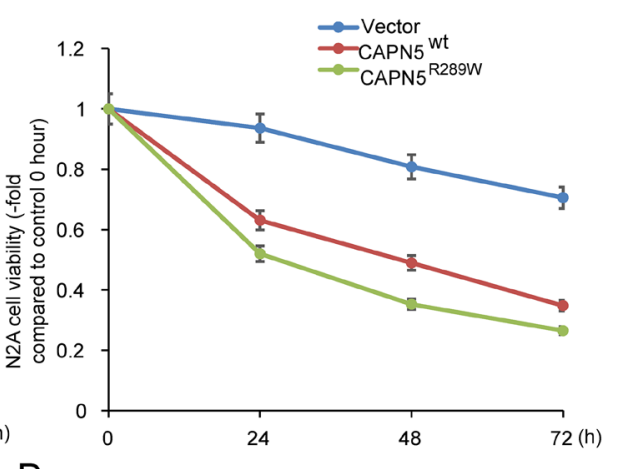

vector CAPN5 $^{\text {Wt }}$ CAPN5 $^{\text {R280W }}$

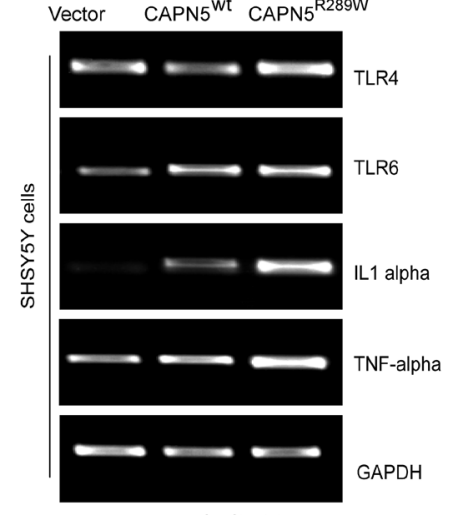

$\mathrm{F}$

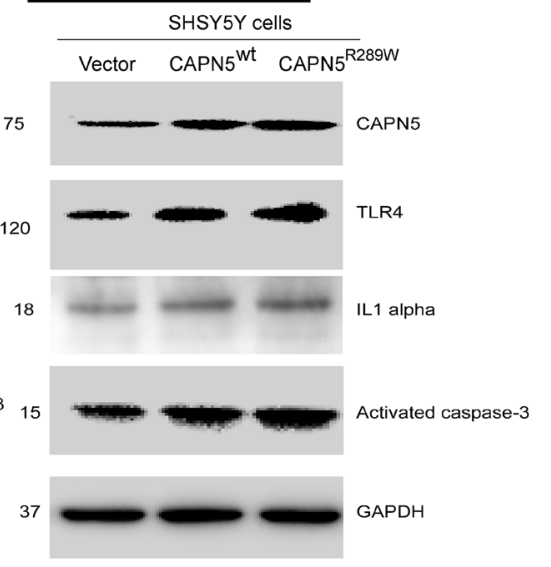

$\mathrm{H}$

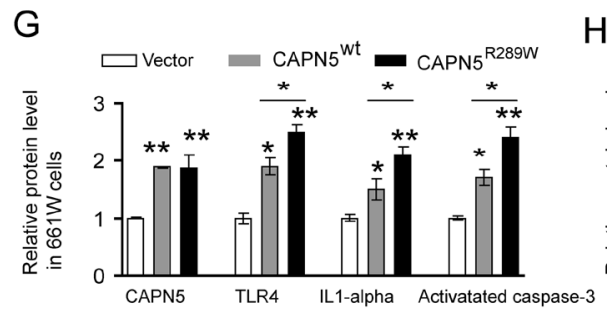

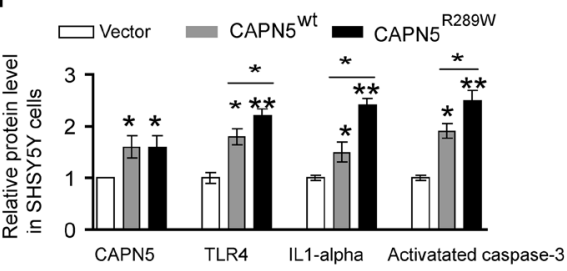

Figure 1: Overexpression CAPN5 induced decreasing viability of neural-like cells, increased expression levels of TLR4, IL1alpha and caspase 3. Photoreceptor-like $661 \mathrm{~W}$ cells and neural-like N2A cells or SHSY5Y cells were transfected with CAPN5 ${ }^{\text {wt }}$ and CAPN5 $5^{\mathrm{R} 289 \mathrm{~W}}$ plasmids respectively, at indicated hours post-transfection. (A) Cell viability of $661 \mathrm{~W}$ cells were measured by MTT assay and calculated. (B) The related viability of N2A cells. After sixty-hour transfections, the 661W cells and SHSY5Y cells were lysed for immunoblot and RT-PCR analysis, respectively. mRNA or protein levels of CAPN5, TLR4, TLR6, IL1alpha, TNFalpha and GAPDH were determined. (C) RT-PCR measurements for 661W cells. (D) RT-PCR measurements for SH-SY5Y cells. Protein levels of CAPN5, TLR4, IL1alpha, and activated caspase 3 were measured by immunoblotting. (E) Representative images for $661 \mathrm{~W}$ cells. (F) Representative images for SHSY5Y cells. (G) The density of bands from (E), and (H) the density of bands from (F) were measured and normalized to GAPDH by Image J and calculated. Values represent mean \pm SEM of density compared with empty vector controls from triplicate experiments. *, $p<0.05,{ }^{* *}, p<0.01$, Kruskal-Wallis test was used. 
data suggest that we successfully produced specific scFvs against human CAPN5 by phage display, and moreover, the antibody fragments also react with mouse CAPN5 in vitro. Both $\mathrm{C} 4 \mathrm{scFv}$ and $\mathrm{C} 8 \mathrm{scFv}$ could be entered into the human living SHSY5Y cells and mouse living $661 \mathrm{~W}$ cells.

\section{CAPN5 scFvs protect $661 \mathrm{~W}$ cells and SHSY5Y cells from $\mathrm{H}_{2} \mathrm{O}_{2}$ and $\mathrm{CAPN5}$ induced apoptosis}

To analyze whether the scFvs against CAPN5 could protect cells from CAPN5-induced apoptosis, we used $\mathrm{H}_{2} \mathrm{O}_{2}$ to induce the death of $661 \mathrm{~W}$ cells. We found that the protein levels of CAPN5 were dramatically increased by $\mathrm{H}_{2} \mathrm{O}_{2}$ treatment. After 2 hours exposure to $\mathrm{H}_{2} \mathrm{O}_{2}$, the viability of $661 \mathrm{~W}$ cells was enhanced by 24 hours ScFv pre-treatment at the indicated concentrations when compared to $\mathrm{H}_{2} \mathrm{O}_{2}$ exposure in the control group (Figure $3 \mathrm{~A}, 3 \mathrm{~B})$. We also found that the $\mathrm{C} 4 \mathrm{scFv}$ significantly reduced the numbers of TUNEL-positive $661 \mathrm{~W}(-32.1 \%$ of control group) and SHSY $5 Y$ cells $(-41 \%$ of control group) compared with $\mathrm{H}_{2} \mathrm{O}_{2}$ exposed controls (-78.9\% in 661 cells, $-87.3 \%$ in SHSY5Y cells) (Figure 3C). These data suggested that CAPN5 scFvs protect cells from $\mathrm{H}_{2} \mathrm{O}_{2}$-induced apoptosis, and neutralize the functions of CAPN5 in response to $\mathrm{H}_{2} \mathrm{O}_{2}$ treatment. To further determine whether CAPN5 ScFvs act as inhibitors of CAPN5 induced apoptosis, we added scFvs alongside overexpression of CAPN5 in $661 \mathrm{~W}$ cells and SHSY5Y
A

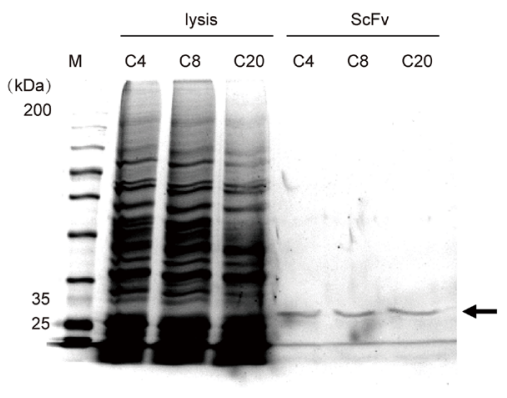

C

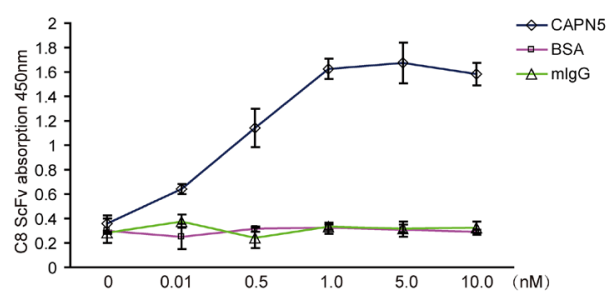

E

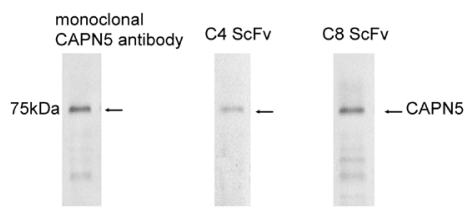

B

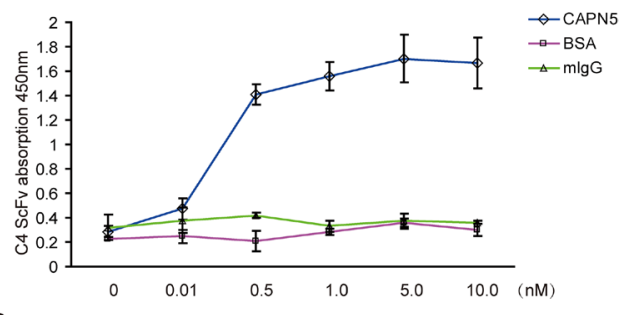

D

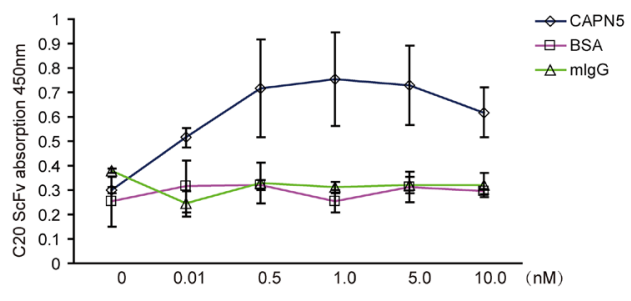

$\mathbf{F}$

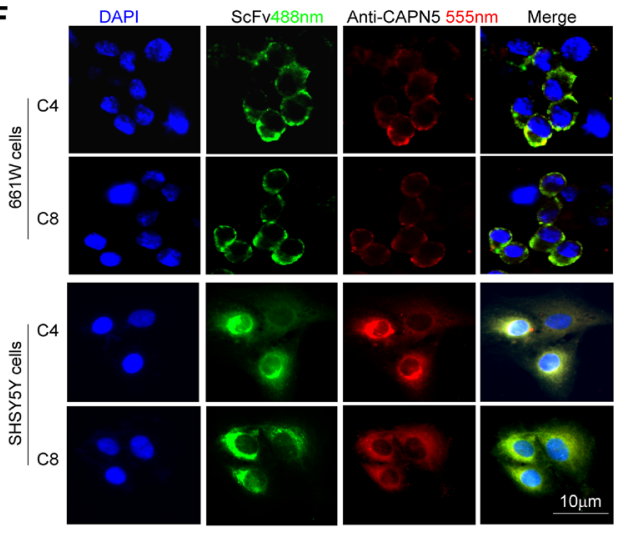

Figure 2: Selection and binding characteristics of CAPN5 scFvs in 661W cells and SHSY5Y cells. Selected C4, C8, C20, scFv-phages were infected into HB2151 strain E. coli. cells and induced by IPTG overnight, purified and detected by SDS-PAGE respectively. (A) Purification of scFvs. The arrow denotes that the approximate molecular weight of scFvs at 30kDa. (B) Values represent mean $\pm \mathrm{SEM} \mathrm{OD}{ }_{450 \mathrm{~nm}}$ for binding of $\mathrm{C} 4 \mathrm{scFv}$ to recombinant CAPN5, normal mouse IgG, and BSA proteins from three independent experiments. The ninety-six well plates were coated with recombinant CAPN5, normal mouse IgG and BSA at the indicated concentrations, and binding capability of scFvs was detected by an anti-c-myc monoclonal antibody followed by goat anti-mouse HRP secondary antibody with ELISA. (C) Binding capability of $\mathrm{C} 8 \mathrm{scFv}$ to indicated recombinant proteins. (D) $\mathrm{C} 20 \mathrm{scFv}$ binding characteristics measured by ELISA. (E) $661 \mathrm{~W}$ cells were lysed and immunoblotted by anti-CAPN5 C4/C8 scFv and monoclonal anti-CAPN5 antibody respectively. The arrows denote the specific molecular weight of CAPN5 at $75 \mathrm{kDa}$. (F) C4 and C8 scFvs bound to living 661W cells and SH-SY5Y cells. C4 or C8 ScFvs (green) and goat anti-CAPN5 (red) were incubated with living $661 \mathrm{~W}$ cells and SH-SY5Y cells at 10 $\mu \mathrm{g} / \mathrm{ml}$ in PBS, for $1 \mathrm{~h}$, cells were then fixed and detected by immunofluorescence. Bar $10 \mu \mathrm{m}$ is shown in the lower photo for all panels. 
cells. After 48 hours of CAPN5 overexpression, scFvs were added to the culture medium. Activated caspase 3 was measured by immunoflourescence (Figure 4A) and caspase 9 levels were decreased by $\mathrm{C} 4$ and $\mathrm{C} 8 \mathrm{scFv}$ treatments when compared to controls. Similar trends were detected in 661 W cells (Figure 4B, 4C) and SHSY5Y cells (Figure 4D, 4E). These data confirm that $\mathrm{scF}$ vs rescue the apoptosis of neuronal cells by targeting CAPN5.

\section{Generation of intracellular antibody fragments against CAPN5}

To generate stable and durable intracellular CAPN5 scFvs in cells we constructed four pSin scFv plasmids. After seventy-two hours post-transfection with pSin $\mathrm{C} 4 \mathrm{ScFv}$, pSin C8ScFv, pSin C10ScFv, and pSin C20ScFv detected all scFv proteins highly expressed in $661 \mathrm{~W}$ cells and SHSY5Y cell lysates, in an immunoblot assay (Figure 5A). We also selected and transfected the pSin $\mathrm{C} 4 \mathrm{scFv}$ into 661W cells and SHSY5Y cells, after forty-eight hours post-transfection, we found co-localization of intracellular C4 ScFv with endogenous CAPN5 in $661 \mathrm{~W}$ cells and SHSY5Y cells by immunofluorescence (Figure 5B). These data suggest that we successfully expressed intracellular specific $\mathrm{C} 4 \mathrm{scFv}$ antibody directly against endogenous CAPN5 in $661 \mathrm{~W}$ photoreceptor like cell and SHSY5Y neural-like cells.

\section{Intracellular antibody against CAPN5 decreased the levels of IL1alpha and activated caspase-3 in cells with CAPN5 overexpression}

To confirm whether the intracellular antibody against CAPN5 could block CAPN5-mediated inflammation and apoptosis, we co-transfected CAPN5 plasmids with pSin scFv plasmids into $661 \mathrm{~W}$ and SHSY5Y cells, respectively. Sixty hours posttransfection, the secretion of IL1alpha in cultured medium as measured by ELISA was increased after CAPN5wt plasmid (Kruskal-Wallis test, $p<0.001$, $51 \pm 6.7 \mathrm{pg} / \mathrm{ml}$ vs $23 \pm 5.14 \mathrm{pg} / \mathrm{ml}$ control in $661 \mathrm{~W}$ cells; $p<0.05,135 \pm 16.7 \mathrm{pg} / \mathrm{ml}$ vs $53 \pm 7.15 \mathrm{pg} / \mathrm{ml}$ control in SHSY5Y cells) and CAPN5 mutant R289W transfection (Kruskal-Wallis test, $p<0.001,102 \pm 11.4 \mathrm{pg} / \mathrm{ml}$ vs control in $661 \mathrm{~W}$ cells; $161 \pm 21.31 \mathrm{pg} / \mathrm{ml}$ vs control in SHSY5Y cells), while the levels of secreted IL1alpha (Kruskal-Wallis test, $p<0.01,661 \mathrm{~W}$ cells, $37 \pm 2.13 \mathrm{pg}$ / $\mathrm{ml}$ in CAPN5wt; $43 \pm 3.18 \mathrm{pg} / \mathrm{ml}$ in CAPN5 R289W; $p<0.01$, SHSY5Y cells, $69 \pm 2.56 \mathrm{pg} / \mathrm{ml}$ in CAPN5 wt, $73 \pm 4.18 \mathrm{pg} / \mathrm{ml}$ in CAPN5 R289W) were reduced after co-transfection of CAPN5 plasmids with pSin C4 $\mathrm{scFv}$ plasmid in both cell lines (Figure 6A, 6B). The expression levels of IL1alpha and activated caspase- 3 were also decreased in co-transfected cells compared with CAPN5 plasmid transfection alone (Figure 6C, 6D).

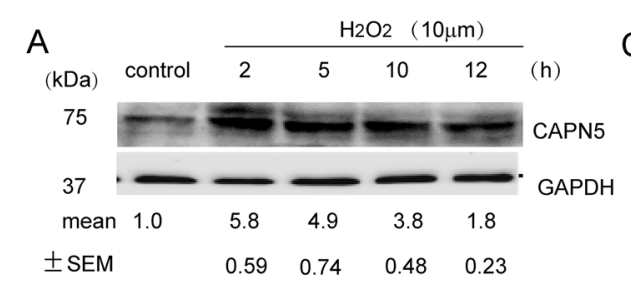

B
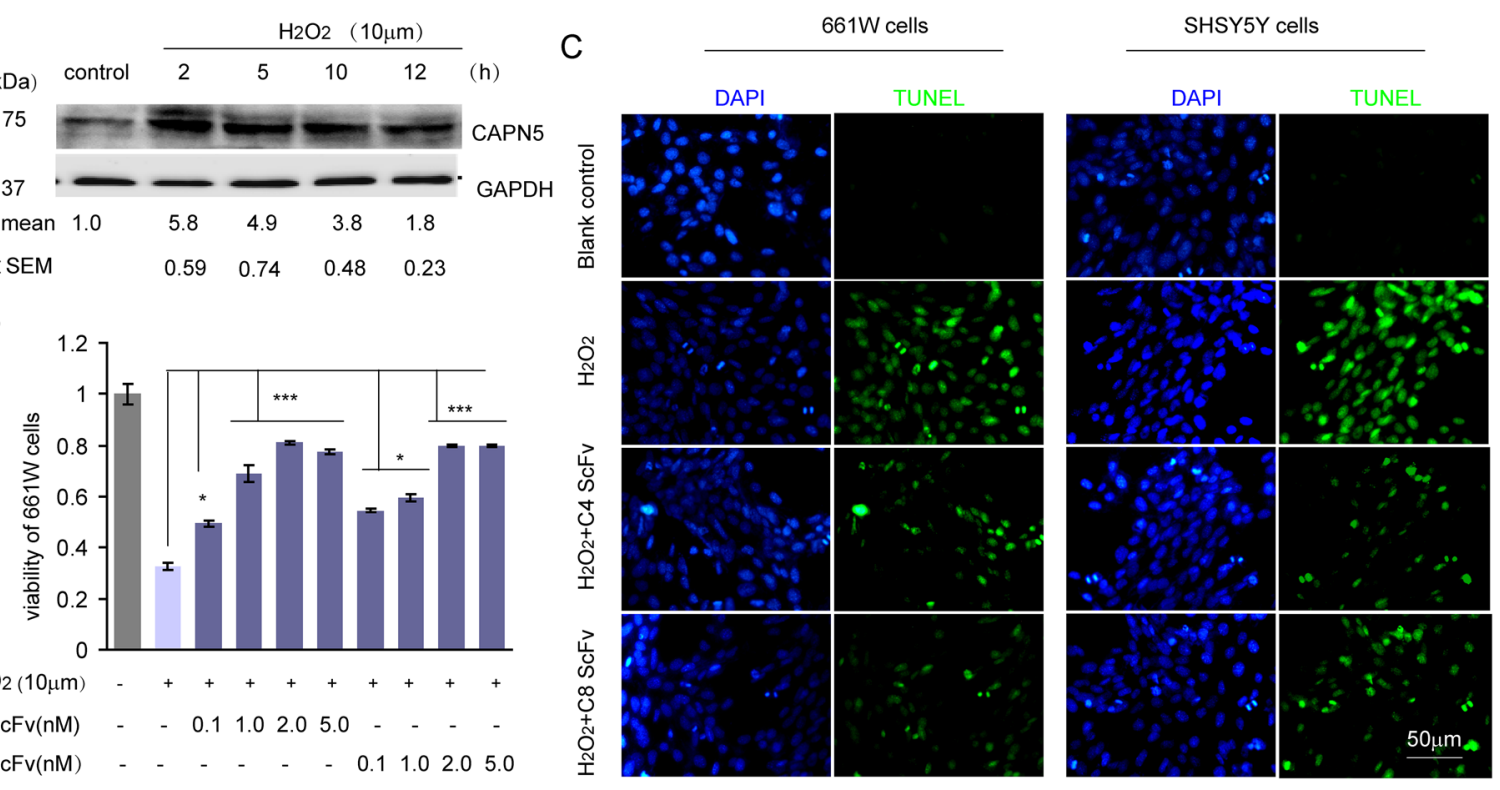

Figure 3: $\mathrm{C} 4$ and $\mathrm{C8}$ scFvs rescued $\mathrm{H}_{2} \mathrm{O}_{2}$-induced cell apoptosis of $661 \mathrm{~W}$ and SHSY5Y cells. (A) $5 \times 10^{6} 661 \mathrm{~W}$ cells were treated with $10 \mu \mathrm{M} \mathrm{H}_{2} \mathrm{O}_{2}$ for the indicated times with serum free medium in six well plates, and cells were lysed for immunoblot assay. Protein levels of CAPN5 and GAPDH were detected and C4 and C8 scFvs are shown. The densitometric values for levels of CAPN5 were measured and shown under each band compared with density of GAPDH. (B) $3 \times 10^{3} 661 \mathrm{~W}$ cells were treated with $\mathrm{H}_{2} \mathrm{O}_{2}$ at $10 \mu \mathrm{M}$ for 2 hours with continued culture in serum free medium in the presence of C4 and C8 ScFvs for $24 \mathrm{~h}$ in 96 well plates. Cell viability was assessed by the MTT assay, and absorbance was read at $450 \mathrm{~nm}$. The values represent mean $\pm \mathrm{SEM}$ of relative cell viability in $\mathrm{ScFvs}$ treatment groups in the absence or presence of $\mathrm{H}_{2} \mathrm{O}_{2}$ compared with controls. ${ }^{*} p<0.05,{ }^{* *} p<0.01$. One way ANOVA and Tukey's post hoc test were used for statistical analysis. (C) $4 \times 10^{4} 661 \mathrm{~W}$ cells or SHSY5Y cells were plated onto cover-slips and treated with $\mathrm{H}_{2} \mathrm{O}_{2}$ for 2 hours in continuous culture in serum free medium in the presence of $\mathrm{C} 4$ or $\mathrm{C} 8 \mathrm{scFvs}$. The cells were fixed for TUNEL staining and DAPI for nuclear staining. Representative images show the positive TUNEL staining (Green) with DAPI positive staining (Blue) cells at 400× magnification. 
A

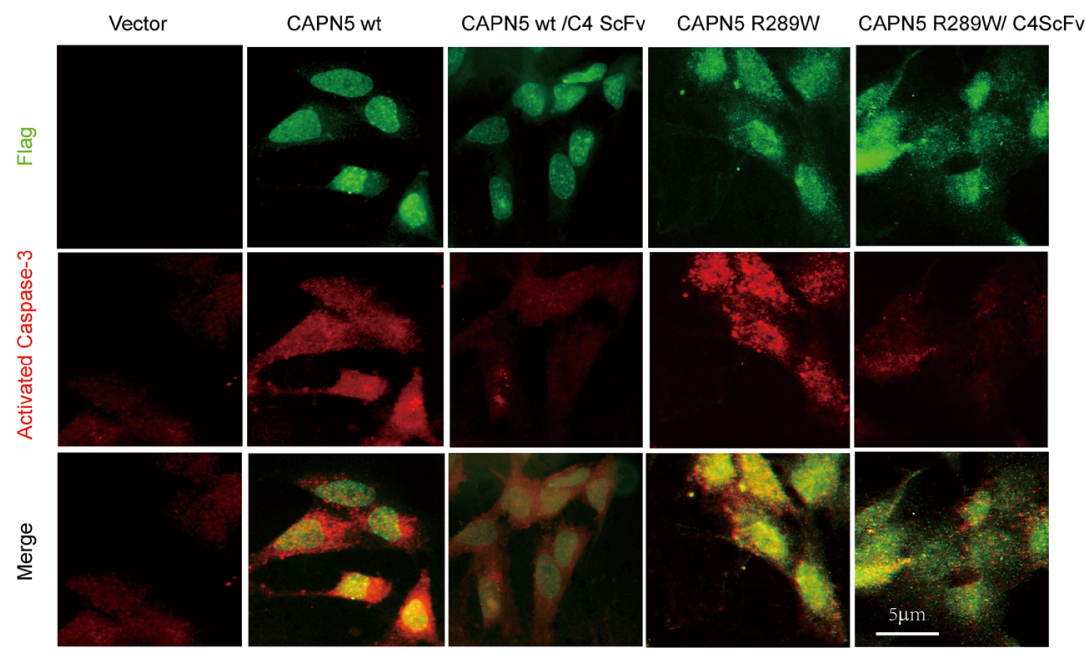

B
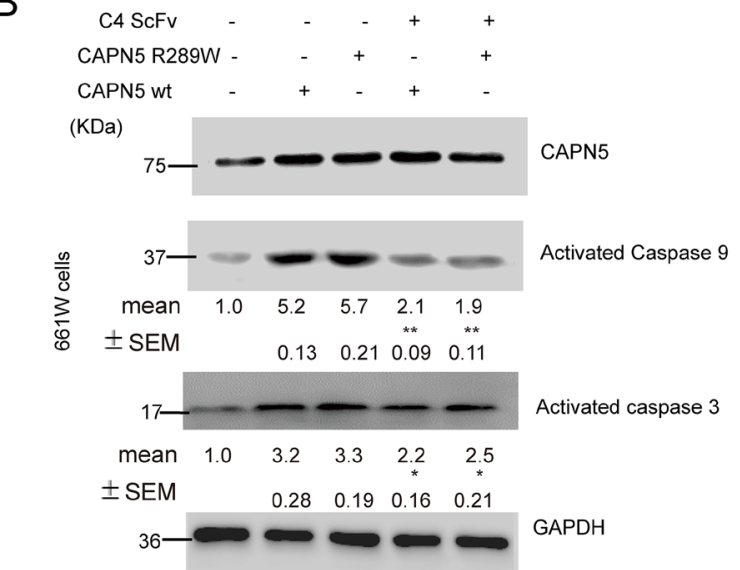

Activated caspase 3

C C8 ScFv

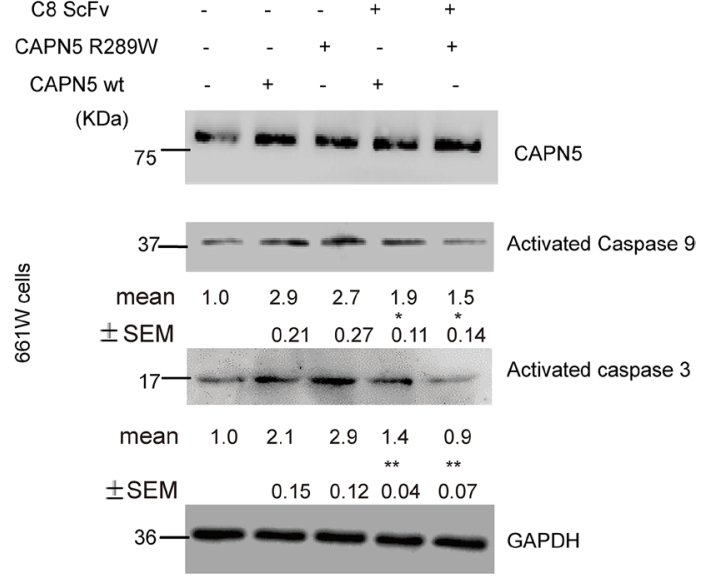

$\mathrm{D}$

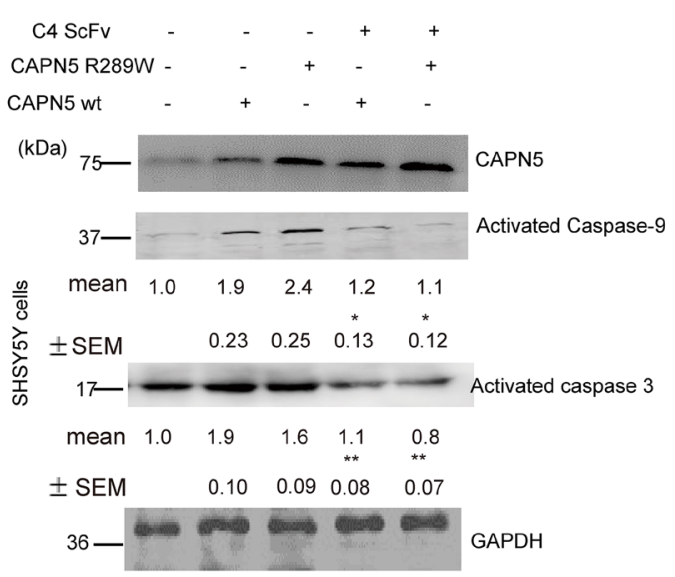

E

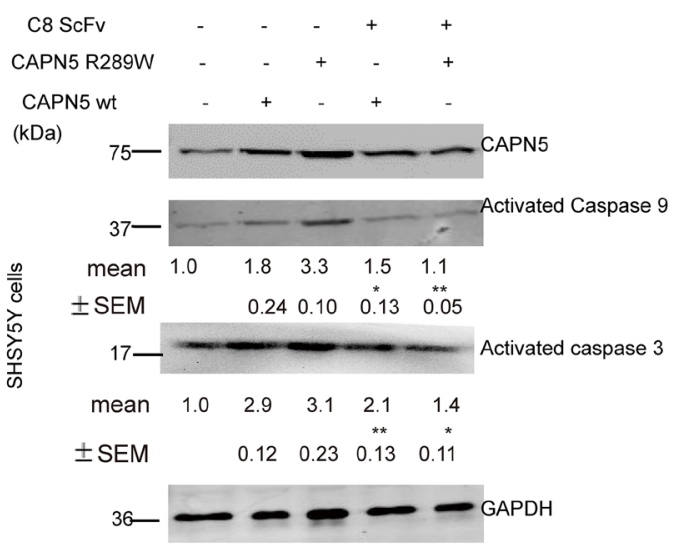

Figure 4: C4 and C8 scFvs reduced activated caspase 3/9 levels induced by CAPN5 overexpression in 661W and SHSY5Y cells. $5 \times 10^{6} 661 \mathrm{~W}$ cells and $3 \times 10^{6}$ SHSY 5 Y cells were transfected with CAPN5 plasmids and empty vectors, and 60 hours posttransfection, the cells were treated continuously with purified $\mathrm{C} 4 \mathrm{scFv}$ or $\mathrm{C} 8 \mathrm{scFv}$ at $10 \mu \mathrm{g} / \mathrm{ml}$. Levels of activated caspase 3/9, and CAPN5 were detected by immunofluorescence and immunoblot respectively. (A) ScFvs reduced immunofluorescence of activated caspase 3 in $661 \mathrm{~W}$ cells after CAPN5/Flag vector transfection. Cells were fixed and stained with anti-Flag followed by green secondary donkey antimouse Alexa 488nm fluorescence antibody; Anti-CAPN5 with red secondary donkey anti-goat Alexa 544nm-labeled antibody. Bar, $5 \mu \mathrm{m}$ in upper panel for all panels in (A). (B) C4 scFv against CAPN5 decreased the levels of activated caspase $3 / 9$ in $661 \mathrm{~W}$ cells. (C) C8 scFv against CAPN5 decreased the levels of activated caspase $3 / 9$ in $661 \mathrm{~W}$ cells. (D) $\mathrm{C} 4 \mathrm{scFv}$ against CAPN5 decreased the levels of activated caspase 3/9 in SHSY5Y cells. (E) C8 scFv against CAPN5 decreased the levels of activated caspase 3/9 in SHSY5Y cells. GAPDH was used as a loading control. The protein levels of CAPN5 and caspase 3/9 were detected, measured and normalized to GAPDH by Image J software. The values presents as mean \pm SEM shown shown under each band from triplicate experiments compared with cells in the absence of ScFv treatments. ${ }^{*} p<0.05,{ }^{* *} p<0.01$. One way ANOVA with Tukey's post hoc test was used for statistical analysis. 
The selected $\mathrm{C} 20 \mathrm{ScFv}$ did not specifically recognize CAPN5, and was used as a negative control (Figure 6). This did not alter the levels of IL1alpha and activated caspase-3 in cells with CAPN5 transfection. These data thus suggest that the intracellular $\mathrm{C} 4 \mathrm{scFv}$ specific against CAPN5, blocked CAPN5-induced secretion of IL1alpha, as well as protein levels of IL1alpha, and activated caspase 3 in $661 \mathrm{~W}$ photoreceptor like cells and SHSY5Y neural-like cells. Previously, we have been found LPS induced highly expression of CAPN5 and IL1 alpha in $661 \mathrm{~W}$ cells (data not shown). Here, we also found that intracellular $\mathrm{C} 4 \mathrm{scFv}$ inhibited IL1alpha secretion from LPS-stimulated $661 \mathrm{~W}$ cells (Figure $6 \mathrm{E})$. Taken together, these data demonstrate that the

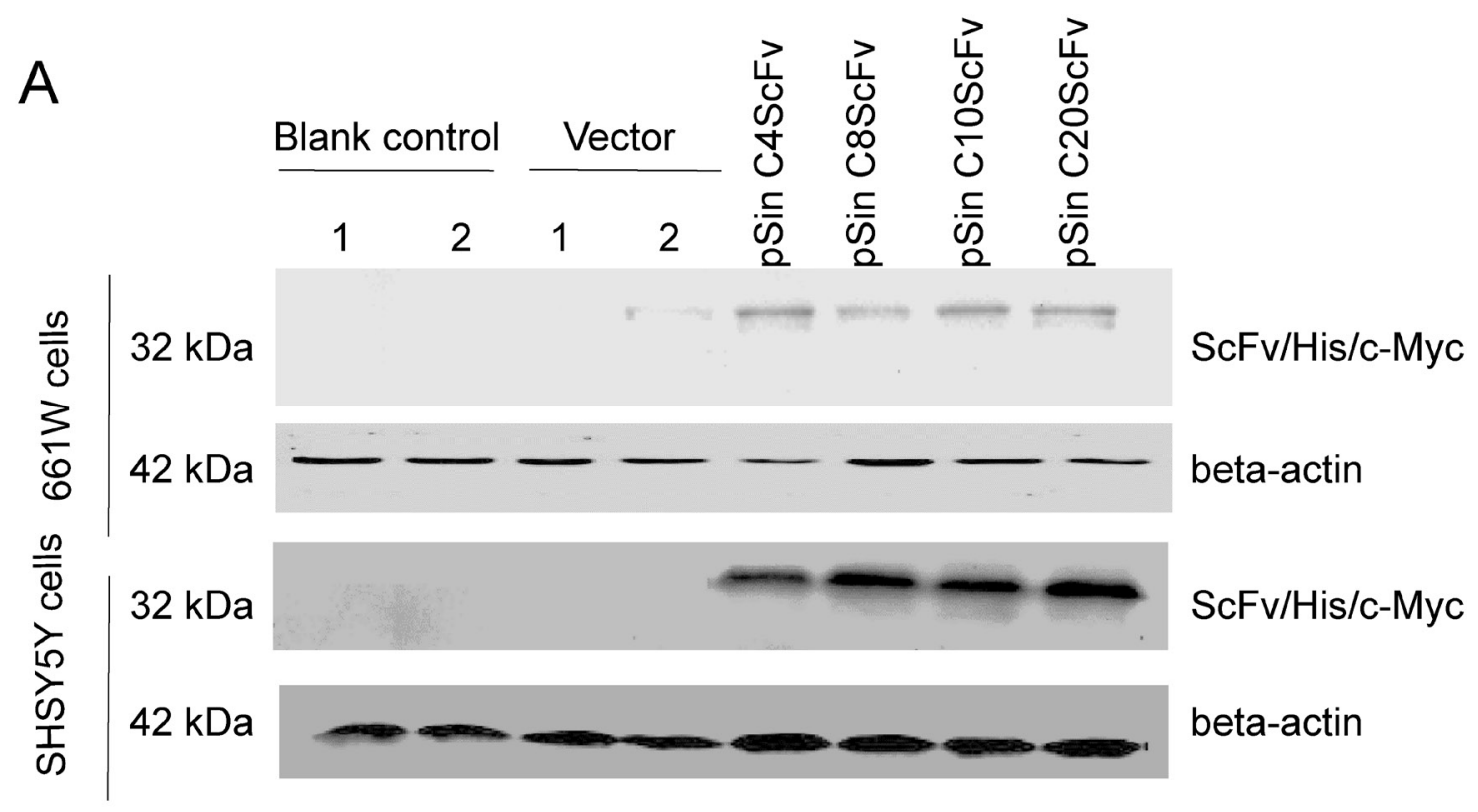

B

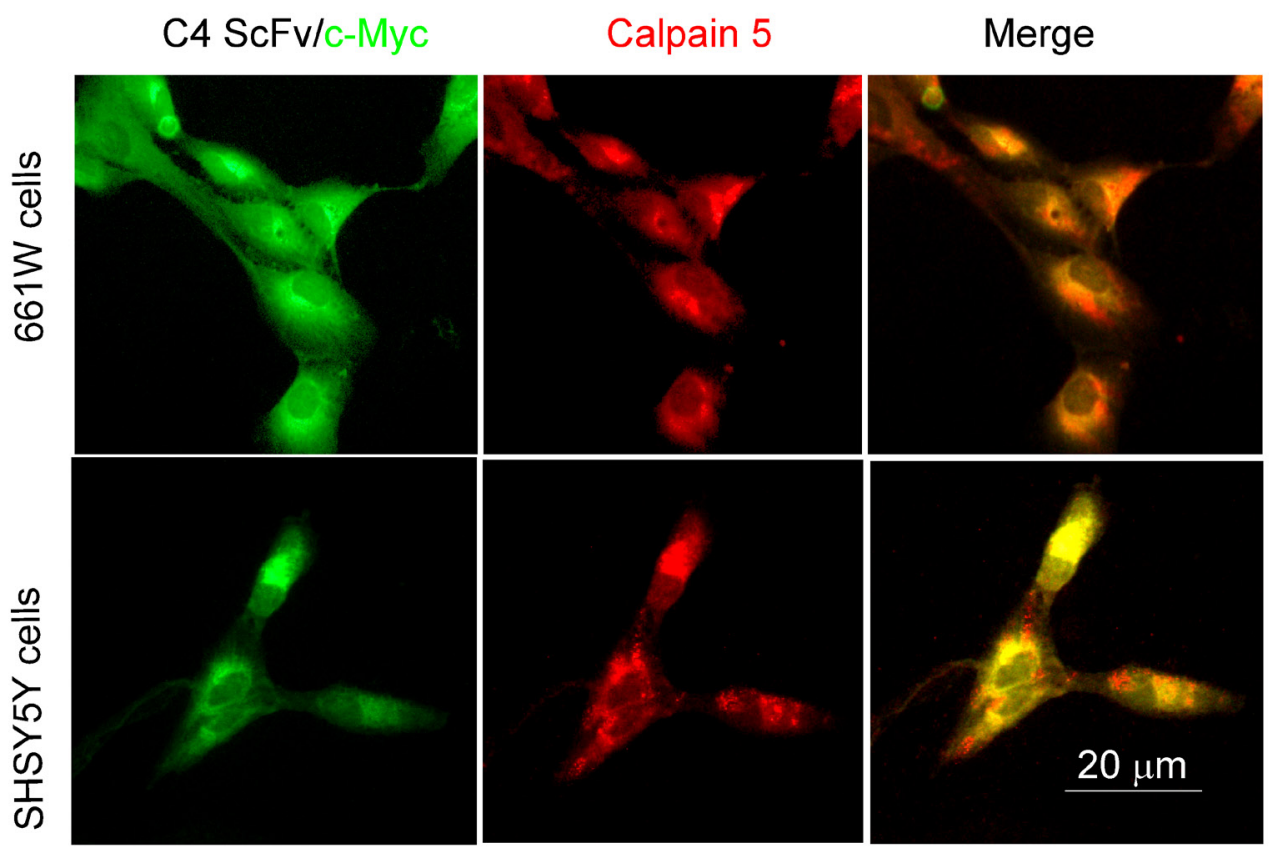

Figure 5: Generation of intracellular CAPN5 antibody fragments in $661 \mathrm{~W}$ cells and SHSY5Y cells. C4 or C8, C10, or $\mathrm{C} 20 \mathrm{scFvs}$ were sub-cloned into the pSin vector and then transfected into $661 \mathrm{~W}$ cells or SH-SY5Y cells. After 60 hours post-transfection, the intracellular scFvs were detected by immunofluorescence or immunoblot. (A) Expression levels of scFvs in $661 \mathrm{~W}$ cells. Vector control was empty vector, blank control was cells in the absence of transfection. 1 and 2 denote duplicate samples. GAPDH was used as a loading control. (B) Immunofluorescence of C4 scFvs colocalized with CAPN5 in 661W cells and SHSY5Y cells. His/myc tagged C4 scFv was detected by anti-c-myc 9E10 antibody and secondary green $488 \mathrm{~nm}$ donkey anti-mouse antibody. Endogenous CAPN5 was detected by goat anti-CAPN5 antibody followed by with red secondary Alexafluor $555 \mathrm{~nm}$ antibody. Images were taken at $400 \times$ magnification. 


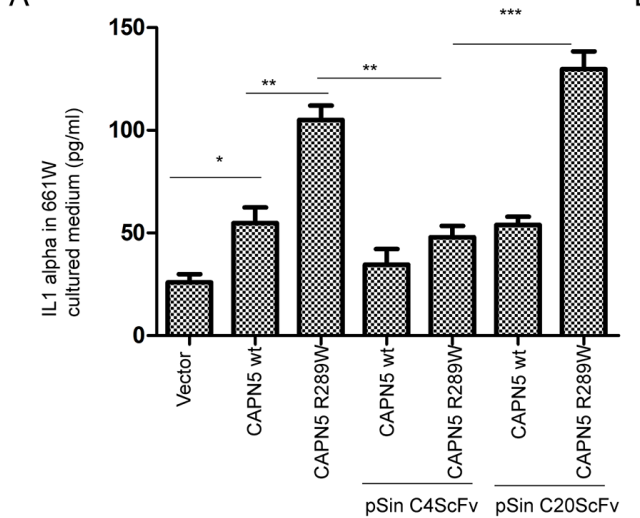

C

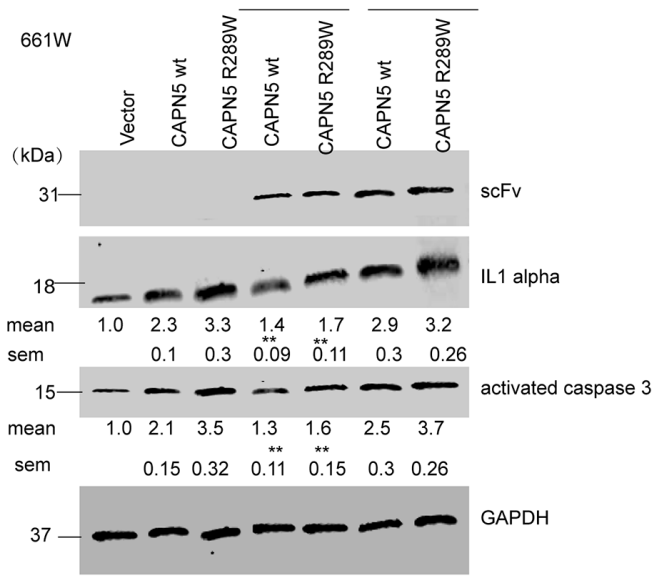

E

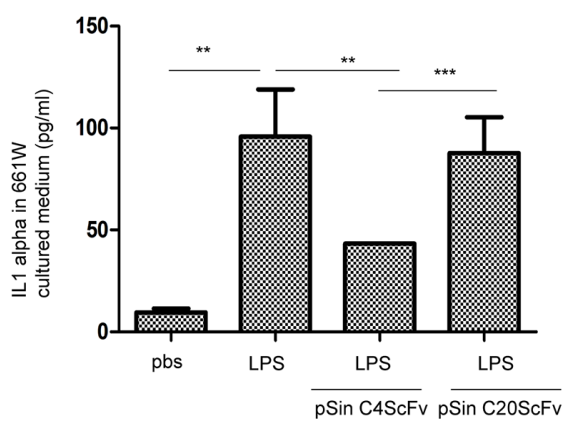

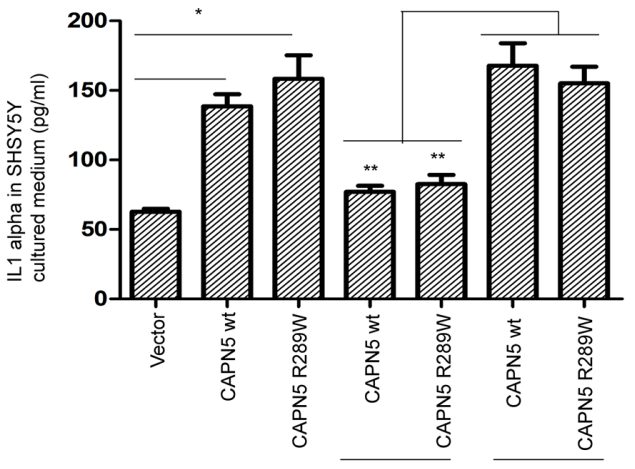

pSin $\mathrm{C} 4 \mathrm{ScF} v \overline{\mathrm{pSin} \mathrm{C} 2 \mathrm{OScFv}}$

$\mathrm{D}$ $\mathrm{pSin} \mathrm{C} 4 \mathrm{ScFv} \quad \mathrm{pSin} \mathrm{C} 20 \mathrm{ScFv}$

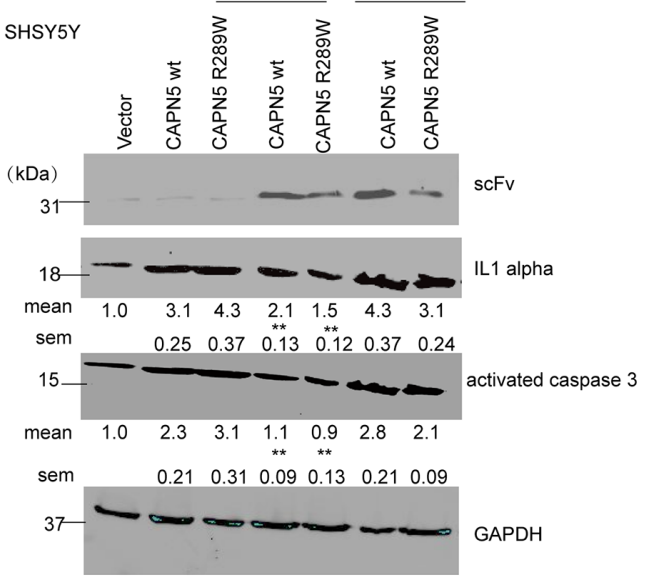

Figure 6: Intracellular CAPN5 antibody fragment inhibited secretion of IL1alpha, and caspase 3 activation induced by overexpression CAPN5 and LPS. $3.0 \times 10^{6} 661 \mathrm{~W}$ cells and $4.0 \times 10^{6} \mathrm{SH}-\mathrm{SY} 5 \mathrm{Y}$ cells were treated with LPS at $100 \mathrm{ng} / \mathrm{ml}$ with serum free medium, then transfected with CAPN5 plasmids, empty vectors, or co-transfected with CAPN5 plasmids and C4 scFv plasmid or C20 scFv plasmid, respectively. After 60 hours post-transfection, culture medium was collected and IL1alpha detected by ELISA. (A) Secretion of IL1alpha in $661 \mathrm{~W}$ cells. (B) Secretion of IL1alpha in SH-SY5Y cells., $p<0.05,{ }^{* *}, p<0.01,{ }^{* * *}, p<0.001$, Kruskal-Wallis test was used. After 60 hours post-transfection, cell lysates were detected by immunoblotting. (C) The protein levels of IL1alpha and activated caspase 3 were inhibited in $661 \mathrm{~W}$ cells with CAPN5 transfections by intracellular scFv transfection. (D) Protein levels of IL1alpha and activated caspase 3 were inhibited in $661 \mathrm{~W}$ cells with CAPN5 transfection by intracellular scFv transfection. The protein levels of IL1alpha was detected by specific antibodies. GAPDH was used as a loading control. The protein levels of IL1alpha and activated caspase 3 were detected and measured by Image $J$ software. The values are presented as mean \pm SEM shown under each band from triplicate experiments compared with cells with CAPN5 vector transfections and by omitting scFv treatments in (C) and (D). " $p<0.05,{ }^{* * *} p<0.01,{ }^{* * *}, p<0.001$. One way ANOVA with Tukey's post hoc test was used for statistical analysis. $3.0 \times 10^{6} 661 \mathrm{~W}$ cells were treated with LPS at $200 \mathrm{ng} / \mathrm{ml}$ for $24 \mathrm{~h}$, then transfected with pSin $\mathrm{C} 4 \mathrm{scFv}$ or pSin $\mathrm{C} 20 \mathrm{scFv}$ for $48 \mathrm{~h}$, cells cultured medium was collected and detected by ELISA. (E) Intracellular $\mathrm{C} 4 \mathrm{scFv}$ decreased the secreted level of IL1alpha in $661 \mathrm{~W}$ cells after LPS treatment. The values are presented as mean \pm SEM shown in graphs from triplicate experiments compared with cells with CAPN5 vector transfections and omitting scFv treatments or C20 scFv plasmid transfection in (A), (B), (E). ${ }^{*} p<0.05,{ }^{* *} p<0.01,{ }^{* * *}, p<0.001$. One way ANOVA with Tukey's post hoc test was used for statistical analysis. 
Table 1: Antibodies used in this study

\begin{tabular}{|c|c|c|}
\hline Antibody & Supplier & Dilution \\
\hline Monoclonal anti-CAPN5 & Santa Cruz Biotechnology, Santa Cruz, CA, USA & $1: 500$ \\
\hline Goat anti-CAPN5 & Santa Cruz Biotechnology & $1: 700$ \\
\hline Monoclonal anti-C-myc tag (9E10) & Santa Cruz Biotechnology & $1: 500$ \\
\hline Monoclonal anti-GAPDH & Beyotime Biotechnology & $1: 800$ \\
\hline Monoclonal anti-activated caspase 3 & Beyotime Biotechnology & $1: 500$ \\
\hline Monoclonal anti-His tag & Beyotime Biotechnology & $1: 400$ \\
\hline Rabbit anti-TLR4 & Boshide Biotechnology, Wuhan, China & $1: 400$ \\
\hline Monoclonal anti-IL1alpha & Boshide Biotechnology & $1: 400$ \\
\hline Rabbit anti-goat IgG HRP & Beyotime Biotechnology & $1: 1000$ \\
\hline Rabbit anti-mouse IgG HRP & Beyotime Biotechnology & $1: 1000$ \\
\hline Rabbit anti-activated caspase 9 & Ruiying Biological, Suzhou, China & $1: 450$ \\
\hline AlexaFluor 488-conjugated donkey anti-mouse IgG & $\begin{array}{l}\text { Jackson ImmunoResearch Laboratories, West } \\
\text { Grove, PA, USA }\end{array}$ & $1: 1000$ \\
\hline AlexaFluor 555-conjugated donkey anti-rabbit IgG & Jackson ImmunoResearch Laboratories & $1: 1000$ \\
\hline Monoclonal anti-M13 phage & Sino Biological. INC., Beijing, China & $1: 2000$ \\
\hline Biotin-conjugated monoclonal anti-C-myc (9E10) & Sigma-Aldrich, St. Louis, MO, USA & $1: 1000$ \\
\hline Extravidin-HRP & Sigma-Adlrich, St.Louis, MO, USA & $1: 1000$ \\
\hline
\end{tabular}

CAPN5-specific intracellular antibody inhibited CAPN5 functions when CAPN5 was overexpressed in neuronal cells or after LPS induced inflammation.

\section{DISCUSSION}

In this study we initially showed that overexpression of CAPN5 decreased viability of neural-like cells, the expression levels of TLR4 and caspase 3 activation were enhanced by CAPN5 overexpression, showing that CAPN5 is either directly or indirectly involved in increased levels of TLR4 and activated caspase 3. Moreover, we also saw increased levels of IL1alpha which is downstream of TLR4 signaling, as a downstream mechanism of autoimmunity pro-inflammation [31]. The enhanced secretion of ILlalpha, and caspase 3 activation result in degeneration of photoreceptor-like cells and neural-like cells by CAPN5 overexpression. Interesting, overexpression of the mutant CAPN5 R289W was decreased viability of neural-like cells and enhanced the higher levels of caspase 3/9 and TLR4/ IL1alpha when compared with wild type CAPN5 overexpression. In agreement with our findings, activated CAPN5 induced increased inflammatory factors through TLR4/6 autoimmunity inflammation pathways in retinal degeneration in ADNIV patients [5, 6]. Previously, we have observed a novel CAPN5 R289W mutant affect ADNIV patients in a Chinese family. We speculated this mutant stabilized catalytic core domain II and enhanced CAPN5 catalytic activation in construct conformation. There is also an evidence have been reported that the mutant R243L increased activation of CAPN5 catalytic core domain to stimulate TLR4 autoimmunity inflammation in $C A P N 5^{R 243 L}$ transgenic mice retina [28]. Thus, we considered that the mutant CAPN5 R289W increased degeneration of photoreceptor cells by activated caspase 3 and TLR4 auto-inflammatory pathway.

It also has been found that in neurodegenerative Huntington's disease, CAPN5 is abnormally activated regulator for proteolytic of htt protein in neural cell death [8]. The evidence presented here suggests that activation of CAPN5 leads to neural degeneration by increased activated caspase 3/9 in cells. Thus, we screened and selected specific scFvs which block CAPN5, we successfully constructed intracellular antibody fragment expression plasmids to express specific scFvs against endogenous CAPN5 in cells. The CAPN5 intracellular antibody fragments inhibited secretion of IL1alpha induced by LPS or CAPN5 overexpression. The intracellular antibody fragment neutralized activation of CAPN5 by overexpression in neural-like cells and protected cells from activated CAPN5-incuded proinflammation and cell apoptosis. Taken together, these findings strongly suggest that CAPN5 activation causes retinal degeneration and is also involved in neuronal degeneration. 
Table 2: Primers used for RT-PCR

\begin{tabular}{|c|c|c|c|c|}
\hline Gene Name & Forward (5'-3') & Reverse (5'-3') & Amplicon Size (bp) & Reference Sequence \\
\hline$m \_T L R 4$ & ATGGCATGGCTTACACCACC & GAGGCCAATTTTGTCTCCACA & 253 & NM_021297.3 \\
\hline m_TLR6 & GATCCCCGGCTCTTCGTAGAT & GACGATTACGTCCACCCACTC & 196 & NM_011604.3 \\
\hline m_IL1alpha & TCTATGATGCAAGCTATGGCTCA & CGGCTCTCCTTGAAGGTGA & 159 & NM_010554.4 \\
\hline m_TNFalpha & GAAATGCCACCTTTTGACAGTG & TGGATGCTCTCATCAGGACAG & 324 & NM_013693.3 \\
\hline$m_{-} G A P D H$ & AATGGATTTGGACGCATTGGT & TTTGCACTGGTACGTGTTGAT & 157 & NM_001289726.1 \\
\hline$h \_T L R 4$ & AGACCTGTCCCTGAACCCTAT & CGATGGACTTCTAAACCAGCCA & 127 & NM_138554.4 \\
\hline h_TLR6 & CGCCACTGACGACTCACTC & CTGCCACAAACCAGCAGTTG & 243 & NM_006068.4 \\
\hline h_ILlalpha & TGAGTGTCTCTGTTGAAAACCTC & GGGGTACTTCTATTGAACGACGA & 162 & NM_000575.4 \\
\hline$h \_T N F$ alpha & ATGATGGCTTATTACAGTGGCAA & GTCGGAGATTCGTAGCTGGA & 231 & NM_000594.3 \\
\hline$h \_G A P D H$ & TGTGGGCATCAATGGATTTGG & ACACCATGTATTCCGGGTCAAT & 81 & NM_002046.5 \\
\hline
\end{tabular}

CAPN5 is a member of the calpain family, but lacks the EF calcium binding domain, it may has similar characteristics and substrates as others calpains, like classical calpain $1 / 2$ in the nerve system and retina [8]. Although calpains have vast numbers of proteases and proteolytic complexes in nerve systems, calpains are very few that are directly enzymatic activated dependent by $\mathrm{Ca}^{2+}$ in signal transduction. In addition, calpains are modulator proteases that perform proteolysis to modulate rather than abolish the function of their substrate [32]. Since, the $\mathrm{Ca}^{2+}$ signaling and proteolysis of CAPN5 need to be further explored to fit CAPN5 into our subject of interest. Moreover, in his study, the precise scFv binding/ blocking domain(s)/epitopes of CAPN5 were still unknown. We have been found purified CAPN5 activity by cleavage of a common calpains' substrate AC-LLYAFC dependent $\mathrm{Ca}^{2+}$ concentration. The $\mathrm{C} 4 \mathrm{scFv}$ antibody inhibited CAPN5 activity of cleavage for AC-LLY-AFC (data not shown). Therefore, the screening of scFv against the specific catalytic domain of CAPN5 and substrates of CAPN5 could be strategies to investigate molecular mechanism underlying its related neuronal degenerative diseases.

Recently, many inhibitors against calpain $1 / 2$ have been generated to inhibit neuronal degeneration and ophthalmic diseases in vitro and in vivo [32-34]. It has been report that calpain-1 is hyperactivated in the $\mathrm{AD}$ brain [35], and calpain inhibitors can improve memory and synaptic function in mice APP overexpressing AD model [36]. Calpain 1/2 inhibitors, ALLNal and SNJ1945 are therapeutically beneficial in LIS1-related lissencephaly [37]. The inhibition of calpain 2 is also benefit to relieving photoreceptor degeneration in retinitis pigmentosa [38]. However, these inhibitors were still not sufficiently specific to distinguish calpains from other proteases in almost all cells. Thus, we firstly screened and generated the specific intracellular anti-CAPN5 scFv to inhibit CAPN5 overexpressing in photoreceptor cells and neuronal like cells. $\mathrm{ScFv}$ offer small size and low immunogenicity and can be used in gene delivery system to target proteins and neutralized harmful protein activations [32]. The intracellular expressed and targeting antibody (intrabody) has been used in therapeutically aims in neurodegenerative diseases [39]. Here, we generated pSin vector encoding $\mathrm{scFv}$ to target intracellular CAPN5 protein, and block CAPN5-induced inflammation and apoptosis in neuronal degenerative processes. We could also be further exploring adeno associated virus (AAV) delivery CAPN5 scFv as a treatment strategy for CAPN5 mutations-linked ADNIV in eye and activated CAPN5 related-neurodegenerative diseases in central nerve system.

In summary, our observations support the view that activated CAPN5 induced activation of TLR4 and caspase 3 pathways in auto-inflammation and apoptosis, thereby leading to degeneration of photoreceptors and neural degeneration. We developed intracellular antibody fragments against cellular CAPN5 and inhibited the process of auto-inflammation and cell death by activated CAPN5 induced. These potential intracellular antibody fragments could be further used for therapy in ADNIV mice model and neurodegenerative diseases.

\section{MATERIALS AND METHODS}

\section{Antibodies and reagents}

Antibodies against the following proteins were used in this study (listed in Table 1): glyceraldehyde3-phosphate dehydrogenase (GAPDH), mouse/human calpain-5 (CAPN5), c-myc tag, His-tag, mouse/human TLR4 and IL1alpha, mouse/human activated caspase 3/9. Secondary antibodies coupled to horseradish peroxidase (HRP) or fluorescein were also obtained (Table 1). Highly purified normal human/mouse immunoglobulin (IgG) and bovine serum protein were obtained from Sino Biological Inc. (Beijing, China). MTT (3, 4, 5-dimethylthiazol2-yl)-2, 5-diphenyltetrazoliumbromide) was used to determine cell viability (R\&D Systems). DAPI (4', 6-diamidino-2-phenylindole) was used to stain cell nuclei. IPTG (isopropyl $\beta$-D-1-thiogalactopyranoside) was used 
to induce expression of protein (Beyotime). Poly-D-lysine (PDL) (Beyotime) was used as a substrate for cell culture. Lipopolysaccharide (LPS, extract from Salmonella enterica serotype enteritidis) (Sigma-Aldrich, Shanghai, China) was used to induce inflammation in cells.

\section{Cell culture}

Human neuroblastoma SHSY5Y cells, mouse neuroblastoma neuro-2a (N2A) cells or mouse photoreceptor like $661 \mathrm{~W}$ cells were cultured in Dulbecco's modified Eagle's medium (DMEM) containing 10\% fetal bovine serum (Fbs). Transfection of SHSY5Y, 661W cells was performed using Lipofectamine 2000 (Invitrogen, Carlsbad, CA, USA) according to the manufacturer's instructions.

\section{Protein purification}

For purification of the human CAPN5 protein, 100 $\mu \mathrm{l}$ of an overnight culture of Escherichia coli. (BL21 strain), harboring the plasmid pET28a encoding the Histagged CAPN5, was used to inoculate $100 \mathrm{~mL}$ of fresh LB-Kan broth, and shaken at $37^{\circ} \mathrm{C}$ for $2 \mathrm{~h}$. Isopropyl $\beta$-D-1-thiogalactopyranoside was then added to a final concentration of $5 \mathrm{mM}$, and incubation was continued for a further $10 \mathrm{~h}$. The Flag-tagged CAPN5 was purified using an $\mathrm{Ni}+$ affinity column.

For purification of the scFvs, phagemid clones were amplified and phages were extracted as described [29]. For production of soluble $\mathrm{ScFv}$ proteins, $1 \mathrm{ml}$ inocula of E. coli HB 2151 strain was infected with a glycerol stock of an individual phage-ScFv clone and transferred into culture flasks for expression of the scFv cassette was induced by isopropyl $\beta$-D-1-thiogalactopyranoside, which was added to give a final concentration of $1 \mathrm{mM}$ isopropyl $\beta$-D-1-thiogalactopyranoside. Shaking was continued overnight. ScFvs were secreted into the culture supernatant and the E. coli periplasm were harvested after osmotic shock. Supernatants were then centrifuged at $10,000 \times \mathrm{g}$ at $4^{\circ} \mathrm{C}$ for $30 \mathrm{~min}$ and clarified by filtration through $0.22 \mu \mathrm{m}$ filters (PALL, Port Washington, NY, USA). Finally, all clarified protein fractions (supernatant and periplasmic fraction) were pooled and passed through a Ni+ affinity column and dialyzed against PBS. Purity of the eluted soluble scFvs was evaluated by SDS-PAGE on $10 \%$ gels. The concentration of the purified scFvs was determined by the BCA technique (Beyotime).

\section{Selection and generation of intracellular $\mathrm{scFv}$}

The selection method of $\mathrm{scFv}$ binding to human CAPN5 was essentially as described [29]. The Tomlinson $\mathrm{I}$ and $\mathrm{J}$ libraries (Geneservice, Nottingham, United Kingdom) and recombinant CAPN5 were used for screening. Briefly, $100 \mu \mathrm{l}$ of $22.5 \mu \mathrm{g} / \mathrm{ml}$ CAPN5 in PBS $\mathrm{pH} 7.4$ were coated overnight at $4^{\circ} \mathrm{C}$ onto a 96 -well tissue culture dish (Jet, biofial, Beijing, China). Wells were then blocked with 3\% BSA (fatty acid free, Merck, Whitehouse Station, NJ, USA) in PBS at room temperature for $1 \mathrm{~h}$. After washing the wells twice with $\mathrm{PBS}, 10^{13}$ phagemid particles in $0.5 \%$ BSA in PBS were added to the wells. After incubation for $40 \mathrm{~min}$ at room temperature, wells were washed eight times with PBS containing $0.1 \%, 0.3 \%$, or $0.5 \%$ Tween-20 and then rinsed twice with PBS, for 5 min each. Bound phages in each well were released by incubation with $100 \mu \mathrm{l}$ trypsin (Beyotime, Hai Men, China) $(10 \mu \mathrm{g} / \mathrm{ml}$ in PBS) for 1 hour at room temperature and collected. For amplification, phages were used to infect the E. coli strain TG1. Bacteria were grown at $37^{\circ} \mathrm{C}$ overnight on TYE plates containing $100 \mu \mathrm{g} / \mathrm{ml}$ ampicillin and $1 \%$ glucose. After three rounds of panning, individual phage clones were selected for ELISA. For phage ELISA, each well of a 96-well plate was coated overnight at $4^{\circ} \mathrm{C}$ with $100 \mu \mathrm{l}$ of $10 \mu \mathrm{g} / \mathrm{ml}$ CAPN5 in PBS, and blocked with $3 \% \mathrm{BSA}$ in PBS for 1 hour at room temperature. Supernatants from individual clones were added to the wells, incubated at room temperature for $40 \mathrm{~min}$ and washed three times with PBST (PBS, 0.1\% Tween 20). Wells were then incubated with a 1:3,000 dilution of the monoclonal mouse anti-M13 horseradish peroxidase (HRP) conjugated antibody (GE Healthcare) in 3\% BSA in PBS for 1 hour at room temperature and washed three times with PBST. Binding of phages was detected using TMB (3, 3', 5, 5'-tetramethylbenzidine; Beyotime). For selection of scFvs, 96 well plates were coated overnight at $4^{\circ} \mathrm{C}$ with $100 \mu \mathrm{l}$ purified recombinant CAPN5 in PBS over a concentration range of $0-10 \mathrm{nM}$. Wells were blocked with 3\% BSA in PBS for 1 hour at room temperature. Individual scFvs $(100 \mu \mathrm{l}, 100 \mathrm{ng} / \mathrm{ml}$ in PBS containing $3 \%$ BSA) were added to the wells, incubated at room temperature for $40 \mathrm{~min}$, and washed with $0.1 \%$ PBST three times. Wells were then incubated with biotin-conjugated mouse anti-c-myc monoclonal antibody 9E10 for 1.5 hours at room temperature, washed three times with $0.1 \%$ PBST, and then incubated with ExtrAvidin-HRP (SigmaAldrich) for 1 hour. Wells were washed, and binding was detected using TMB as a substrate.

The sequences of selected clones were determined with the primer LMB (5'-CAG GAA ACA GCT ATG AC$\left.3^{\prime}\right)$ by the dideoxy chain terminating method. Sequencing was repeated three times for verification. For constructs of intracellular expressed scFvs, we subcloned c-myc and His-tagged scFvs into the pSin Puro vector from the $\mathrm{pSin}$ EGFP Puro plasmid using BamH I and EcoR I.

\section{RT-PCR}

The 661W and SHSY5Y cells were transfected with CAPN5 plasmids, the cells were lysed and total RNA was extracted using TRIzol reagent (Invitrogen, USA) respectively, and cDNA was synthesized using reverse transcriptase (TIANGEN, Beijing, China). The 
RNA (1\%) was reverse transcribed to complementary deoxyribonucleic acid, and 20 ng of complementary DNA was used as the template for RT-PCR. The amplification cycling reactions (35 cycles) were performed as follows: 2 mins at $95^{\circ} \mathrm{C}, 30$ seconds at $60^{\circ} \mathrm{C}$ and 1 mins at $72^{\circ} \mathrm{C}$. The primers' information were used in this study (as shown in Table 2). The mRNA levels of TLR4, TLR6, IL1alpha, TNFalpha and GAPDH were determined for each experiment.

\section{Immunostaining}

For living cells immunostaining, the living cells on coverslips were incubated with scFvs which tagged with His and C-myc at $10 \mu \mathrm{g} / \mathrm{ml}$ in PBS for 2 hours at $37^{\circ} \mathrm{C}$ incubator, then discard scFvs and fixed cells with 4\%PFA, incubated cells with mouse anti-his tag antibody (1:500) and goat anti-CAPN5 antibody (1:700) overnight at $4^{\circ}$ Covernight, after PBS washing, incubated coverslips with secondary Alexa 488nm donkey anti-mouse IgG and Alexa 555nm donkey anti-goat IgG antibodies for 1 hour at room temperature. For normal immunostaining, 661W and SH-SY5Y cells were cultured for 40 hours on PDLcoated glass slides and fixed in 4\% paraformaldehyde (PFA) as described [30]. After 48 hours pSin C4 scFv plasmid transfection, the cells on coverslips were fixed and incubated with mouse anti-C-myc antibody (1:500) and goat anti-CAPN5 antibody $(1: 700)$ at $4^{\circ}$ Covernight, then following incubated with secondary Alexa $488 \mathrm{~nm}$ donkey anti-mouse IgG and Alexa 555nm donkey antigoat IgG antibodies for $1 \mathrm{~h}$ at room temperature. DAPI was used to stain nuclei. Images were captured in digital format using a Zeiss microscope (Carl Zeiss, Chester, VA).

\section{Western blot analysis}

Western blot analysis was performed as described [30]. For CAPN5 or scFvs overexpression experiments and $\mathrm{scFv}$ protein treatment experiments, Cells were transfected with plasmids for $60 \mathrm{~h}$, or treated with scFvs at $10 \mu \mathrm{g} / \mathrm{ml}$ in DMEM with $0.1 \%$ FBS for 24 hours, after transfections and treatments, cells were collected and lysed. The total cell proteins were separated by SDS-PAGE and transferred to PVDF membrane, the membranes were incubated with rabbit anti-activated caspase 3, caspase 9 antibodies, goat anti-CAPN5, monoclonal anti-IL1alpha, anti-His, or anti$\mathrm{C}$-myc antibodies in 5\% milk which diluted in PBS at $4^{\circ}$ Covernight respectively, after washing with $0.1 \%$ TBST, the membrane incubated with donkey anti-mouse/goat IgG HRP secondary antibodies for 1 hour at room temperature.

For $\mathrm{H}_{2} \mathrm{O}_{2}$ exposure experiments, cells were pretreated with $10 \mu \mathrm{M} \mathrm{H} 2 \mathrm{O} 2$ for 2, 6, 12, 24 hours, then the cells were collected and lysed for immunoblot analysis as above. Bands were visualized with an enhanced chemiluminescence system kit (Beyotime). Signals were detected and quantified using Image $\mathrm{J}$ software (National Institutes of Health, Bethesda, MD, USA).

\section{Determination of cell viability}

Cells were suspended in DMEM/F-12 medium to a concentration of $5 \times 10^{4}$ cells $/ \mathrm{ml}$, and $100 \mu \mathrm{l}$ was added to each well of a 96-well plate. After treatment with transfection of CAPN5 plasmids, scFvs, or normal control plasmids for 24,48 , or $60 \mathrm{~h}$, cells were incubated separately with $10 \mu \mathrm{l}$ MTT $(500 \mu \mathrm{g} / \mathrm{mL})$ for $4 \mathrm{~h}$. The culture medium was then removed, and $100 \mu$ dimethylsulfoxide (DMSO) was added to each well, followed by a $30 \mathrm{~min}$ incubation period at $25^{\circ} \mathrm{C}$. Absorbance was measured spectrophotometrically at $540 \mathrm{~nm}$.

\section{Statistics}

Statistical analyses were performed with SPSS 13.0 software (IBM Corporation, Armonk, NY, USA). All data are presented as means \pm SEM unless otherwise specified. Student's t-test was used for comparisons in experiments with only two groups. In experiments with more than two groups, ANOVA was performed followed by Tukey's post hoc test for pairwise comparisons among three and greater than three groups. For analysis of more than two groups of non-parametric data, the Kruskal-Wallis test was used.

\section{Abbreviations}

ADNIV: autosomal dominant neovascular inflammatory vitreoretinopathy; CAPN5: calpain 5calcium-activated cysteine protease; scFv: single chain fragment of variable; IL1: interlukin 1; TNF: tumor necrosis factor; TLR: toll like receptor; PBS: phosphate buffer saline; GAPDH: glyceraldehyde-3-phosphate dehydrogenase.

\section{Author contributions}

W.Y. designed and carried out experiments, F.G. designed experiment and discussed. X.Z. and Z.M.S discussed. W.Y., F.G. wrote manuscript.

\section{ACKNOWLEDGMENTS}

We thank FanFan Li for plasmid construct.

\section{CONFLICTS OF INTEREST}

The authors declare no conflicts of interest.

All experiments were conducted in compliance with the ARRIVE guidelines.

\section{FUNDING}

This work was supported by grants from the Chinese National Program on Key Basic Research Project (973 Program, 2013CB967502, F.G.), the Natural Science 
Foundation of China (81201181, F.G., 81473295 \& 81670882, ZM.S.), the Natural Science Foundation of Zhejiang Province, China (LQ17H120004, W.Y.), Science Technology project of Zhejiang Province (2017C37176, F.G.), Wenzhou city grant (Y20160146, W.Y.;Y20140633, F.G.), Wenzhou Medical University grant (KYQ151202, W.Y.) and Eye Hospital at Wenzhou Medical University (YNZD201602, F.G.).

\section{REFERENCES}

1. Matena K, Boehm T, Dear N. Genomic organization of mouse Capn5 and Capn6 genes confirms that they are a distinct calpain subfamily. Genomics. 1998; 48:117-120.

2. Waghray A, Wang DS, McKinsey D, Hayes RL, Wang KK. Molecular cloning and characterization of rat and human calpain-5. Biochem Biophys Res Commun. 2004; 324:46-51.

3. Tlucek PS, Folk JC, Sobol WM, Mahajan VB. Surgical management of fibrotic encapsulation of the fluocinolone acetonide implant in CAPN5-associated proliferative vitreoretinopathy. Clin Ophthalmol. 2013; 7:1093-1098.

4. Bassuk AG, Yeh S, Wu S, Martin DF, Tsang SH, Gakhar L, Mahajan VB. Structural modeling of a novel CAPN5 mutation that causes uveitis and neovascular retinal detachment. PLoS One. 2015; 10:e122352.

5. Rowell HA, Bassuk AG, Mahajan VB. Monozygotic twins with CAPN5 autosomal dominant neovascular inflammatory vitreoretinopathy. Clin Ophthalmol. 2012; 6:2037-2044.

6. Mahajan VB, Skeie JM, Bassuk AG, Fingert JH, Braun TA, Daggett HT, Folk JC, Sheffield VC, Stone EM. Calpain-5 mutations cause autoimmune uveitis, retinal neovascularization, and photoreceptor degeneration. PLoS Genet. 2012; 8:e1003001.

7. Sáez ME, Grilo A, Morón FJ, Manzano L, MartínezLarrad MT, González-Pérez A, Serrano-Hernando J, Ruiz A, Ramírez-Lorca R, Serrano-Ríos M. Interaction between Calpain 5, Peroxisome proliferator-activated receptorgamma and Peroxisome proliferator-activated receptordelta genes: a polygenic approach to obesity. Cardiovasc Diabetol. 2008 25; 7:23.

8. Gafni J, Hermel E, Young JE, Wellington CL, Hayden MR, Ellerby LM. Inhibition of calpain cleavage of huntingtin reduces toxicity: accumulation of calpain/caspase fragments in the nucleus. J Biol Chem. 2004; 279:20211-20220.

9. Clemens LE, Weber JJ, Wlodkowski TT, Yu-Taeger L, Michaud M, Calaminus C, Eckert SH, Gaca J, Weiss A, Magg JC, Jansson EK, Eckert GP, Pichler BJ, et al. Olesoxime suppresses calpain activation and mutant huntingtin fragmentation in the BACHD rat. Brain. 2015; 138(Pt 12):3632-3653.

10. González A, Sáez ME, Aragón MJ, Galán JJ, Vettori P, Molina L, Rubio C, Real LM, Ruiz A, Ramírez-Lorca R.
Specific haplotypes of the CALPAIN-5 gene are associated with polycystic ovary syndrome. Hum Reprod. 2006; 21:943-951.

11. Schaefer KA, Toral MA, Velez G, Cox AJ, Baker SA, Borcherding NC, Colgan DF, Bondada V, Mashburn CB, Yu CG, Geddes JW, Tsang SH, Bassuk AG, Mahajan VB. Calpain-5 Expression in the Retina Localizes to Photoreceptor Synapses. Invest Ophthalmol Vis Sci. 2016; 57:2509-2521.

12. Singh R, Brewer MK, Mashburn CB, Lou D, Bondada V, Graham B, Geddes JW. Calpain 5 is highly expressed in the central nervous system (CNS), carries dual nuclear localization signals, and is associated with nuclear promyelocytic leukemia protein bodies. J Biol Chem. 2014; 289:19383-19394.

13. Baudry M, Bi X. Calpain-1 and Calpain-2: The Yin and Yang of Synaptic Plasticity and Neurodegeneration. Trends Neurosci. 2016; 39:235-245.

14. Camins A, Verdaguer E, Folch J, Pallàs M. Involvement of calpain activation in neurodegenerative processes. CNS Drug Rev. 2006; 12:135-148.

15. Schoch KM, Evans HN, Brelsfoard JM, Madathil SK, Takano J, Saido TC, Saatman KE. Calpastatin overexpression limits calpain-mediated proteolysis and behavioral deficits following traumatic brain injury. Exp Neurol. 2012; 236:371-382.

16. McGinn MJ, Kelley BJ, Akinyi L, Oli MW, Liu MC, Hayes RL, Wang KK, Povlishock JT. Biochemical, structural, and biomarker evidence for calpain-mediated cytoskeletal change after diffuse brain injury uncomplicated by contusion. J Neuropathol Exp Neurol. 2009; 68:241-249.

17. Amini M, Ma CL, Farazifard R, Zhu G, Zhang Y, Vanderluit J, Zoltewicz JS, Hage F, Savitt JM, Lagace DC, Slack RS, Beique JC, Baudry M, et al. Conditional disruption of calpain in the CNS alters dendrite morphology, impairs LTP, and promotes neuronal survival following injury. $\mathrm{J}$ Neurosci. 2013; 33:5773-5784.

18. Ma M. Role of calpains in the injury-induced dysfunction and degeneration of the mammalian axon. Neurobiol Dis. 2013; 60:61-79.

19. Raynaud F, Marcilhac A. Implication of calpain in neuronal apoptosis. A possible regulation of Alzheimer's disease. FEBS J. 2006; 273:3437-3443.

20. Samantaray S, Ray SK, Banik NL. Calpain as a potential therapeutic target in Parkinson's disease. CNS Neurol Disord Drug Targets. 2008; 7:305-312.

21. Rosenberger TA. Targeting calpain-mediated proteolysis and peptide signaling as a strategy to reduce injury in multiple sclerosis. J Neurochem. 2014; 130:161-164.

22. Yang J, Weimer RM, Kallop D, Olsen O, Wu Z, Renier N, Uryu K, Tessier-Lavigne M. Regulation of axon degeneration after injury and in development by the endogenous calpain inhibitor calpastatin. Neuron. 2013; 80:1175-1189. 
23. Sanges D, Comitato A, Tammaro R, Marigo V. Apoptosis in retinal degeneration involves cross-talk between apoptosisinducing factor (AIF) and caspase-12 and is blocked by calpain inhibitors. Proc Natl Acad Sci U S A. 2006; 103:17366-17371.

24. Barnes TM, Hodgkin J. The tra-3 sex determination gene of Caenorhabditis elegans encodes a member of the calpain regulatory protease family. EMBO J. 1996; 15:4477-4484.

25. Syntichaki P, Xu K, Driscoll M, Tavernarakis N. Specific aspartyl and calpain proteases are required for neurodegeneration in C. elegans. Nature. 2002; 419:939-944.

26. Bennett SR, Folk JC, Kimura AE, Rusell SR, Stone EM, Raphtis EM. Autosomal dominant neovascular inflammatory vitreoretinopathy. Ophthalmology. 1990; 97:1125-35; discussion 1135-1136.

27. Wert KJ, Skeie JM, Bassuk AG, Olivier AK, Tsang SH, Mahajan VB. Functional validation of a human CAPN5 exome variant by lentiviral transduction into mouse retina. Hum Mol Genet. 2014; 23:2665-2677.

28. Wert KJ, Bassuk AG, Wu WH, Gakhar L, Coglan D, Mahajan M, Wu S, Yang J, Lin CS, Tsang SH, Mahajan VB. CAPN5 mutation in hereditary uveitis: the R243L mutation increases calpain catalytic activity and triggers intraocular inflammation in a mouse model. Hum Mol Genet. 2015; 24:4584-4598.

29. Eteshola E. Isolation of $\mathrm{scFv}$ fragments specific for monokine induced by interferon-gamma (MIG) using phage display. J Immunol Methods. 2010; 358(1-2):104-110.

30. Makhina T, Loers G, Schulze C, Ueberle B, Schachner M, Kleene R. Extracellular GAPDH binds to L1 and enhances neurite outgrowth. Mol Cell Neurosci. 2009; 41:206-218.

31. Shalhoub J, Falck-Hansen MA, Davies AH, Monaco C. Innate immunity and monocyte-macrophage activation in atherosclerosis. J Inflamm (Lond). 2011; 8:9.

32. Ono Y, Saido TC, Sorimachi H. Calpain research for drug discovery: challenges and potential. Nat Rev Drug Discov. 2016; 15:854-876.
33. Chen BS, Gray JA, Sanz-Clemente A, Wei Z, Thomas EV, Nicoll RA, Roche KW. SAP102 mediates synaptic clearance of NMDA receptors. Cell Rep. 2012; 2:1120-1128.

34. Briz V, Parkash J, Sánchez-Redondo S, Prevot V, Suñol C. Allopregnanolone prevents dieldrin-induced NMDA receptor Internalization and neurotoxicity by preserving GABA (A) receptor function. Endocrinology. 2012; 153:847-860.

35. Taniguchi S, Fujita Y, Hayashi S, Kakita A, Takahashi H, Murayama S, Saido TC, Hisanaga S, Iwatsubo T, Hasegawa M. Calpain-mediated degradation of p35 to p25 in postmortem human and rat brains. FEBS Lett. 2001; 489:46-50.

36. Higuchi M, Iwata N, Matsuba Y, Takano J, Suemoto T, Maeda J, Ji B, Ono M, Staufenbiel M, Suhara T, Saido TC. Mechanistic involvement of the calpain-calpastatin system in Alzheimer neuropathology. FASEB J. 2012; 26:1204-1217.

37. Yamada M, Yoshida Y, Mori D, Takitoh T, Kengaku M, Umeshima H, Takao K, Miyakawa T, Sato M, Sorimachi $\mathrm{H}$, Wynshaw-Boris A, Hirotsune S. Inhibition of calpain increases LIS1 expression and partially rescues in vivo phenotypes in a mouse model of lissencephaly. Nat Med. 2009; 15:1202-1207.

38. Shinde V, Kotla P, Strang C, Gorbatyuk M. Unfolded protein response-induced dysregulation of calcium homeostasis promotes retinal degeneration in rat models of autosomal dominant retinitis pigmentosa. Cell Death Dis. 2016; 7:e2085.

39. Patel P, Kriz J, Gravel M, Soucy G, Bareil C, Gravel C, Julien JP. Adeno-associated virus mediated delivery of a recombinant single-chain antibody against misfolded superoxide dismutase for treatment of amyotrophic lateral sclerosis. Mol Ther. 2014; 22:498-510. 